\title{
Granular cell tumor in axillary region: A rare entity
}

\author{
KAMIL POHLODEK ${ }^{1}$, PETER JÁNI ${ }^{2}$ and IVETA MEČIAROVÁ ${ }^{2}$ \\ ${ }^{1}$ Second Department of Gynecology and Obstetrics, Comenius University of Bratislava, \\ Faculty of Medicine, 82606 Bratislava; ${ }^{2}$ Alpha Medical Pathology, Ltd., 84101 Bratislava, Slovakia
}

Received October 18,2017; Accepted December 6, 2017

DOI: $10.3892 / \mathrm{mco} .2018 .1568$

\begin{abstract}
A granular cell tumor (GCT), is a rare soft tissue tumor which may occur throughout the body, usually in the head and neck, skin or subcutaneous tissues of the trunk and upper extremities, and female genital region. A total of $5-8 \%$ of all cases of GCTs occur in the breast. GCT of the breast may mimic breast cancer both clinically and radiologically. GCTs are usually benign and solitary; however, approximately $2 \%$ occur as malignant tumors. Benign GCTs are treated with wide local excision and are associated with a good prognosis. The current case report presents findings in a patient with a benign form of GCT in a rare location, specifically in the axillary region.
\end{abstract}

\section{Introduction}

Granular cell tumor (GCT) is a benign rare tumor that usually affects head and neck. GCT was first identified in tongue in 1854 by Weber (1) and then described in breast by Abrikossoff (2) by the name of granular cell myoblastoma. GCTs were considered to arise from Schwann cells, histiocytes, fibroblasts, myocytes or intestinal mesenchymal cells. Nowadays, the accepted theory claims nerve sheath origin of the tumour $(3,4)$. These tumors may occur throughout the body, usually in the head and neck, skin or subcutaneous tissues of the trunk and upper extremities, breasts and female genital region. $5-8 \%$ of all cases of GCTs occur in the breast $(5,6)$. They are usually benign and solitary; however, approximately $2 \%$ occur as malignant tumors, and $5-10 \%$ as multiple lesions (6). It is important to differentiate between this tumor and breast carcinoma because they share similarities in the diagnostic picture. Benign GCTs are treated with wide local excision and are associated with a good prognosis. We report on our findings in a patient with benign form of GTC in a rare location, specifically in the axillary region.

Correspondence to: Dr Kamil Pohlodek, Second Department of Gynecology and Obstetrics, Comenius University of Bratislava, Faculty of Medicine, Ružinovská 6, 82606 Bratislava, Slovakia E-mail:kpohlodek@gmail.com

Key words: breast, axilla, granular cell tumor

\section{Case report}

A 43-year-old Asian woman felt a tumor-like lump in the anterior axillary line outside of the right breast, and visited our Breast Unit in June, 2016. Mammography suggested a circumscribed, round, radiopaque lesion with unsharp contours in the right axillary region (Fig. 1A). Breast ultrasonography revealed an oval-shaped, low-echoic tumor of unclear aetiology. Infiltrating ductal carcinoma could not be excluded. A ultrasound guided large core-needle biopsy of the tumor was provided. Histologic examination of the core biopsy specimen pointed to benign form of GCT. Lumpectomy was performed and benign granular cell tumor was diagnosed by postoperative histopathologic examination (Fig. 1B-E). The surgically removed specimen was fixed using $10 \%$ neutral buffered formalin for $24 \mathrm{~h}$. The fixed specimen was trimmed with a scalpel to fit into a tissue cassette. It was processed in an automated tissue processing machine (BenchMark XT; Ventana Medical Systems, Inc., Tucson, AZ, USA). The processing included dehydration, clearing, and embedding, in which the specimens were infiltrated with paraffin wax to create paraffin blocks. These blocks were cut with a rotary microtome (Leica RM2235, Leica Biosystems $\mathrm{GmbH}$, Nussloch, Germany) to produce $5 \mu \mathrm{m}$ sections. The sections were then stained with hematoxylin and eosin (H\&E). Histological evaluation of the surgical specimens revealed tumor cells with a distinctive granular eosinophilic cytoplasm associated with typical nuclei, without increase in nuclear division or another signs of malignancy. Benign breast parenchyma and mature fat tissue was present between the tumor structures (Fig. 1B and C). Definitive diagnosis of GCT was established using immunohistochemistry (IHC). The immunostaining for S100 protein (mouse monoclonal antibody to S100; clone 4C4.9; cat. no. ab4066; 1:100 dilution, incubation for $30 \mathrm{~min}$ at $25^{\circ} \mathrm{C}$; Abcam, Cambridge, UK) and CD68 (mouse monoclonal antibody, clone C68/684; cat. no. ab201340; 1:100 dilution, incubation for $30 \mathrm{~min}$ at $25^{\circ} \mathrm{C}$; Abcam, Cambridge, UK) revealed positive results (Fig. 1D and E). IHC analysis of the tumor with anti-cytokeratins antibody (mouse monoclonal antibody to pan Cytokeratin; clone AE1/AE3 + 5D3; cat. no. ab86734; 1:200 dilution, incubation for $30 \mathrm{~min}$ at $37^{\circ} \mathrm{C}$; Abcam, Cambridge, UK) showed negative results. There was also diffuse steroid receptors (estrogen and progesteron receptor) negativity. The post-operative course was uneventful and the patient was discharged home on post-operative 

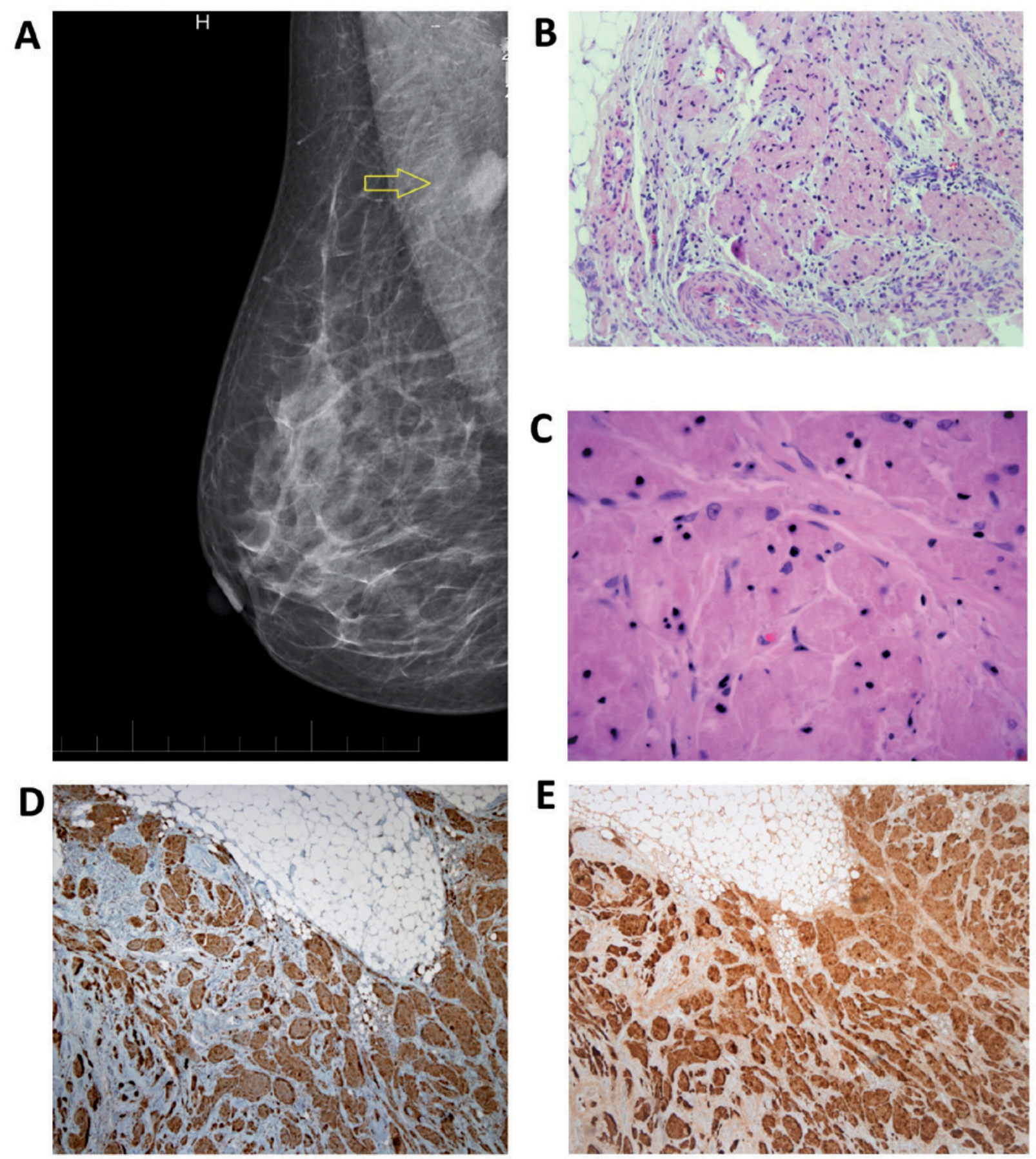

Figure 1. A circumscribed radiopaque lesion i with unsharp contour (arrow) in the right axilla in X-ray digital mammography (A). Granular cell tumor (hematoxilin and eosin staining): Nests of large cells with abundant granular eosinophilic cytoplasm and small nuclei (magnification, x40) (B). Large, round and oval, slightly irregular cells with abundant granular eosinophilic cytoplasm with small, uniform, central nuclei, with inconspicuous nucleoli (magnification, x200) (C). The immunostaining for CD68 (D) and S100 protein (E) revealed positive results (magnification, x100).

day 7. The patient is now 4 months post-surgery and remains disease-free. Written informed consent was obtained from the patient.

\section{Discussion}

GCTs account for an incidence of $0.5 \%$ among soft tissue tumors (3-6). It may occur throughout the body, usually in the head and neck, skin or subcutaneous tissues of the trunk and upper extremities. Recently, Costa Almeida et al (7) published a case report of GCT on the upper limb and reviewed 21 patients with this GCT localization from the literature. When occurring in the breast, as it occurs in 5-8\% of all cases of GCT, they present mostly as painless rounded nodules $(4,6)$. GCT of the breast may mimic breast cancer both clinically and radiologically (8-10). These lesions have been defined as ranging from a round well-circumscribed mass to an indistinct or spiculated lesion on mammography $(8,9)$. Microcalcifications are not normally a feature of GCTs. On ultrasound, GCTs can present as 
solid, poorly marginated lesions with marked posterior shadowing or as more benign-appearing well-circumscribed solid masses $(8,9)$. MRI findings in a patient with GCT were described by Scaranelo et al (10). In contrast to clinical findings, mammography, ultrasonography and MRI positron emission tomography (PET) with 2-[fluorine-18] fluoro-2-deoxy-d-glucose (FDG) can correctly differentiate GCT from a malignant tumor (11). Fine-needle aspiration cytology and frozen section methods are inadequate for definitive diagnosis of GCT (12). The large core-needle biopsy did accurately predict a GCT in our patient.

The appearance of a GCT in axillary region is extremely rare. Aoyama et al (3), reported in their study of six cases of GCTs, a 54-year-old woman with a GCT in the left axillary cavity, which is very similar to our patient. Another patient with similar location of GCT in the upper outer quadrant of the right breast which appeared to be attached to the underlying pectoralis major muscle, was described by Patel et al (9). The mammographic appearence of the GCT was very similar to the patient from our case report. A pediatric GCT in a 15 -year-old female in the right upper outer quadrant with no associated lymphadenopathy was recently refered by Heinzerling et al (13). Delaloye et al (14) reported a rare case of benign GCT of the breast associated with multiple similar lesions of the scalp, the right shoulder, the right flank, the abdominal wall and the vulva, treated with wide excision. Al-Ahmadie et al (15) documented in their report a GCT of the breast coexisting with an ipsilateral infiltrating ductal carcinoma, infiltrated each other. Coates et al (16) reported a case of a patient with a large infra-mammary fold GCT, the management of which required a multidisciplinary operative approach due to extensive chest wall invasion. Malignant forms of GCTs are very rare (1-3\% of all GCT cases). Chen et al (6) and Akahane et al (12) described malignant GCTs in breast. Criteria for malignancy are not consistent; adjacent tissue and/or vascular invasion, high mitotic activity, and size $>4-5 \mathrm{~cm}$ were discussed, but only the presence of metastases was accepted as explicit criterion $(6,7)$. No data exist about the efficacy of adjuvant therapy in GCT treatment.

GCTs are macroscopically, solid, firm tumours with a yellowish-white cross sectional surface $(10,11,13)$. The histogenesis of GCT remains uncertain, however the hypothesis of a neural or neuroectodermal origin is supported by the presence of the S-100 protein, typically expressed by these neoplastic cells, and by the similar ultrastructural features of the tumour cells and Schwann cells (Fig. 1E). On pathological examination they can be identified using both microscopic and immunohistochemical features. The cells have a distinctive granular eosinophilic cytoplasm associated with typical nuclei (Fig. 1B and C). Immunohistochemically they are positive for S100 protein, CD68 (Fig. 1D) and neuron specific endolase (NSE). Fine and Li (17) suggested interaction between expression of calretinin and the alpha-subunit of inhibin in granular cell tumors.

In conclusion, GCT of the breast is a usually benign disease of the breast which may mimic breast cancer both clinically and radiologically. Its presentation in axillary region is very rare. The definitive diagnosis is made by immunohistochemical examination. Clinicians should be aware of this finding in the differential diagnosis of breast and axillary masses to prevent overtreatment.

\section{References}

1. Weber CO: Anatomische untersuchung einer hypertrophischen zunge nebst bemerkungen über die neubildung quergestreifter muskelfasern anatomical examination of a hypertrophic tongue as well as remarks on the new formation of transverse muscle fibers. Virchows Arch A Pathol Anat 7: 115-125, 1954.

2. Abrikossoff AI: Weitere untersuchungen über myoblastenmyome. Virchows Arch Pathol Anat Physiol Klin Med 280: 723-740, 1931.

3. Aoyama K, Kamio T, Hirano A, Seshimo A and Kameoka S: Granular cell tumors: A report of six cases. World J Surg Oncol 10: 204, 2012

4. Pergel A, Yucel AF, Karaca AS, Aydin I, Sahin DA and Demirbag N: A therapeutic and diagnostic dilemma: Granular cell tumor of the breast. Case Rep Med 2011: 972168, 2011.

5. Gogas J, Markopoulos C, Kouskos E, Gogas H, Mantas D, Antonopoulou $\mathrm{Z}$ and Kontzoglou $\mathrm{K}$ : Granular cell tumor of the breast: A rare lesion resembling breast cancer. Eur J Gynaecol Oncol 23: 333-334, 2002.

6. Chen J, Wang L, Xu J, Pan T, Shen J, Hu W and Yuan X: Malignant granular cell tumor with breast metastasis: A case report and review of the literature. Oncol Lett 4: 63-66, 2012

7. Costa Almeida CE, Caroço T, Silva M and Albano MN: Abrikossoff's tumour on the upper limb: A rare presentation. BMJ Case Rep 2017: pii: bcr-2017-222006, 2017.

8. Yang WT, Edeiken-Monroe B, Sneige N and Fornage BD: Sonographic and mammographic appearances of granular cell tumors of the breast with pathological correlation. J Clin Ultrasound 34: 153-160, 2006.

9. Patel A, Lefemine V, Yousuf SM and Abou-Samra W: Granular cell tumour of the pectoral muscle mimicking breast cancer. Cases J 1: 142, 2008.

10. Scaranelo AM, Bukhanov K, Crystal P, Mulligan AM and O'Malley FP: Granular cell tumour of the breast: MRI findings and review of the literature. Br J Radiol 80: 970-974, 2007.

11. Hoess C, Freitag K, Kolben M, Allgayer B, Laemmer-Skarke I, Nathrath WB, Avril N, Roemer W, Schwaiger M and Graeff H: FDG PET evaluation of granular cell tumor of the breast. J Nucl Med 39: 1398-1401, 1998.

12. Akahane K, Kato K, Ogiso S, Sakaguchi K, Hashimoto M, Ishikawa A, Kato T, Fuwa Y, Takahashi A and Kobayashi K: Malignant granular cell tumor of the breast: Case report and literature review. Breast Cancer 22: 317-323, 2015.

13. Heinzerling NP, Koehler SM, Szabo S and Wagner AJ: Pediatric granular cell tumor of the breast: A case report and review of the literature. Case Rep Surg 2015: 568940, 2015.

14. Delaloye JF, Seraj F, Guillou L, Genton CY, Anciaux-Le Teno D, Schnyder P and De Grandi P: Granular cell tumor of the breast: A diagnostic pitfall. Breast 11: 316-319, 2002.

15. Al-Ahmadie H, Hasselgren PO, Yassin R and Mutema G: Colocalized granular cell tumor and infiltrating ductal carcinoma of the breast. Arch Pathol Lab Med 126: 731-733, 2002.

16. Coates SJ, Mitchell K, Olorunnipa OB, DeSimone RA, Otterburn DM and Simmons RM: An unusual breast lesion: Granular cell tumor of the breast with extensive chest wall invasion. J Surg Oncol 110: 345-347, 2014.

17. Fine SW and Li M: Expression of calretinin and the alpha-subunit of inhibin in granular cell tumors. Am J Clin Pathol 119: 259-264, 2003. 